\title{
Changes in polyamines content associated with zygotic embryogenesis in the Brazilian pine, Araucaria angustifolia (Bert.) O. Ktze.
}

\author{
LEANDRO V. ASTARITA ${ }^{1}$, WALTER HANDRO ${ }^{1}$ and ENY I.S. FLOH ${ }^{1,2}$
}

(received: October 24, 2001; accepted: February 5, 2003)

\begin{abstract}
Changes in polyamines associated with zygotic embryogenesis in the Brazilian pine, Araucaria angustifolia (Bert.) O. Ktze.). Changes in the polyamine content were analyzed in different embryo developmental stages and tissues during seed development in the conifer Araucaria angustifolia (Bert.) O. Ktze. Free polyamine contents varied according to the tissue and stage of embryo development, the highest levels occurring in the embryonic axis at the early stages, when putrescine and spermidine were most abundant. The levels of spermidine were higher from the stage where cotyledons arise, whereas putrescine decreases. The putrescine/spermine+spermidine ratio was higher during the initial phases of seed development, corresponding to cell multiplication and elongation, with a decrease in the final stages, corresponding to stabilization of the dry matter content.
\end{abstract}

Key words - Araucaria angustifolia, embryogenesis, polyamines

RESUMO - (Alterações nos níveis das poliaminas durante a embriogênese zigótica do pinheiro brasileiro, Araucaria angustifolia (Bert.) O. Ktze.). As variações nos conteúdos de poliaminas foram analisadas em diferentes estágios e tecidos durante o desenvolvimento da semente de Araucaria angustifolia (Bert.) O. Ktze. O conteúdo de poliaminas livres variou de acordo com o tecido e o estágio de desenvolvimento, com os maiores níveis observados no eixo embrionário nos estágios iniciais, sendo a putrescina e espermidina as mais abundantes. A partir do estágio de aparecimento dos cotilédones, o nível de espermidina aumentou, enquanto o nível de putrescina decresceu. A relação putrescina/spermina+espermidina foi mais elevada durante as fases iniciais do desenvolvimento da semente, correspondendo à multiplicação e alongamento, com um decréscimo nos estágios finais, quando ocorre a estabilização do conteúdo da matéria seca.

Palavras-chave - Araucaria angustifolia, embriogênese, poliaminas

\section{Introduction}

Araucaria angustifolia (Bert.) O. Ktze, Brazilian pine, belongs to the most primitive genus amongst the conifers, and it is the only native conifer of economic importance in Brazil. In this species, attempts have been made to use tissue cultures as an alternative in reforestation programs, with little success. In this regard, it has been difficult to induce somatic embryogenesis from somatic embryos in this species (Astarita \& Guerra 2000, Guerra et al. 2000). The ability of pre-cotyledonary zygotic embryos to produce embryogenic cultures is restricted to a few months, disappearing when cotyledon development starts (Astarita \& Guerra 1998). On the other hand, there are few studies concerning the physiological and biochemical aspects of embryo development in Araucaria (Owens et al. 1997). Astarita et al. (2003) have identified several alterations in protein and

\footnotetext{
1. University of São Paulo, Institute of Biosciences, Department of Botany, Plant Cell Biology Laboratory, Caixa Postal 11461, 05422-970 São Paulo, Brazil.

2._Corresponding author: floheny@ib.usp.br
}

aminoacid profiles during the zygotic embryogenesis in Araucaria angustifolia, associated with characteristic morphological events. The identification of biochemical markers during zygotic embryogenesis could be useful to improve protocols for inducing somatic embryogenesis.

Polyamines (PAs) are compounds present in all eucariotic cells (Heby \& Persson 1990), occurring as free or conjugated forms with phenolic compounds and molecules of low molecular weight, or linked to macromolecules and to the cell wall (Galston \& KaurSawhney 1990, Bajaj \& Rajam 1996, Aribaud et al. 1999). In plants, PAs are synthesized in large amounts in young tissues (meristems and growing tissues), and are also present at high levels in quiescent seeds from different species (Santanen \& Simola 1999). PAs have been regarded as a new class of plant growth regulators, hormonal second- messengers, and one of the reserves of carbon and nitrogen in cultured tissues (Flores \& Filner 1985, Altman \& Levin 1993, Kakkar et al. 2000).

The crucial role of PAs in somatic embryogenesis (Minocha et al. 1993, Minocha et al. 1999) includes certain conifers (Montague et al. 1978, Montague et al. 1979, Baker et al. 1983, Robie \& Minocha 1989, 
Amarasinghe et al. 1996, Minocha et al. 1999, Santanen \& Simola 1999). Minocha et al. (1999) observed changes in the metabolism of polyamines during the development of zygotic and somatic embryos in Pinus radiata $\mathrm{D}$. Don, and demonstrated characteristic parallel changes in these two processes, involving major changes in the Putrescine/Spermidine ratio during the development of both types of embryos. Furthermore, the relationship among PAs content was different in the developing embryos and the non-differentiating residual tissue.

This work describes the changes in free polyamines content during different stages of zygotic embryogenesis in Araucaria angustifolia.

\section{Material and methods}

Plant material - Female cones of Araucaria angustifolia (Bert.) O. Kuntze were harvested in the summer (1998), from December to March (stages 1 to 6) in a natural population (Campos do Jordão State Park, São Paulo, Brazil). Harvest dates corresponded to the sequential development stages from which samples were taken for biochemical analysis. The final harvest date was determined by the time when seeds were able to germinate (stage 6).

Harvest dates were used to identify different stages of embryo development (figure 1). Samples harvested in stage 1 (figure 1a) exhibited an immature embryo, a mucilaginous megagametophyte and a suspensor attached to the embryonic axis. After stage 3, the embryo was already organized with a primordial cotyledon structure.

Although small cotyledons were present in stage 3, they could only be excised following stage 4 . Immature and mature seeds were removed from the cones and dissected to separate the gametophyte, embryonic axis and cotyledon tissues when present. Two replicates ( 10 seeds) per stage were used. Tissue samples were stored at $-20^{\circ} \mathrm{C}$ before biochemical analysis. Polyamines - Tissue samples were frozen and homogenized with 3.5\% PCA ( tissue: PCA ratio 1:4 w/v), with hexylamine (1-aminohexane) as an internal standard. The samples were incubated in ice for $1 \mathrm{~h}$ and centrifuged at $20,000 \mathrm{~g}$ for $20 \mathrm{~min}$. Aliquots of supernatants containing free PAs, were dansylated with dansyl chloride $\left(10 \mathrm{mg} \cdot \mathrm{ml}^{-1}\right.$ acetone) together with saturated $\mathrm{Na}_{2} \mathrm{CO}_{3}(1: 1 \mathrm{v} / \mathrm{v})$, according to Minocha et al.
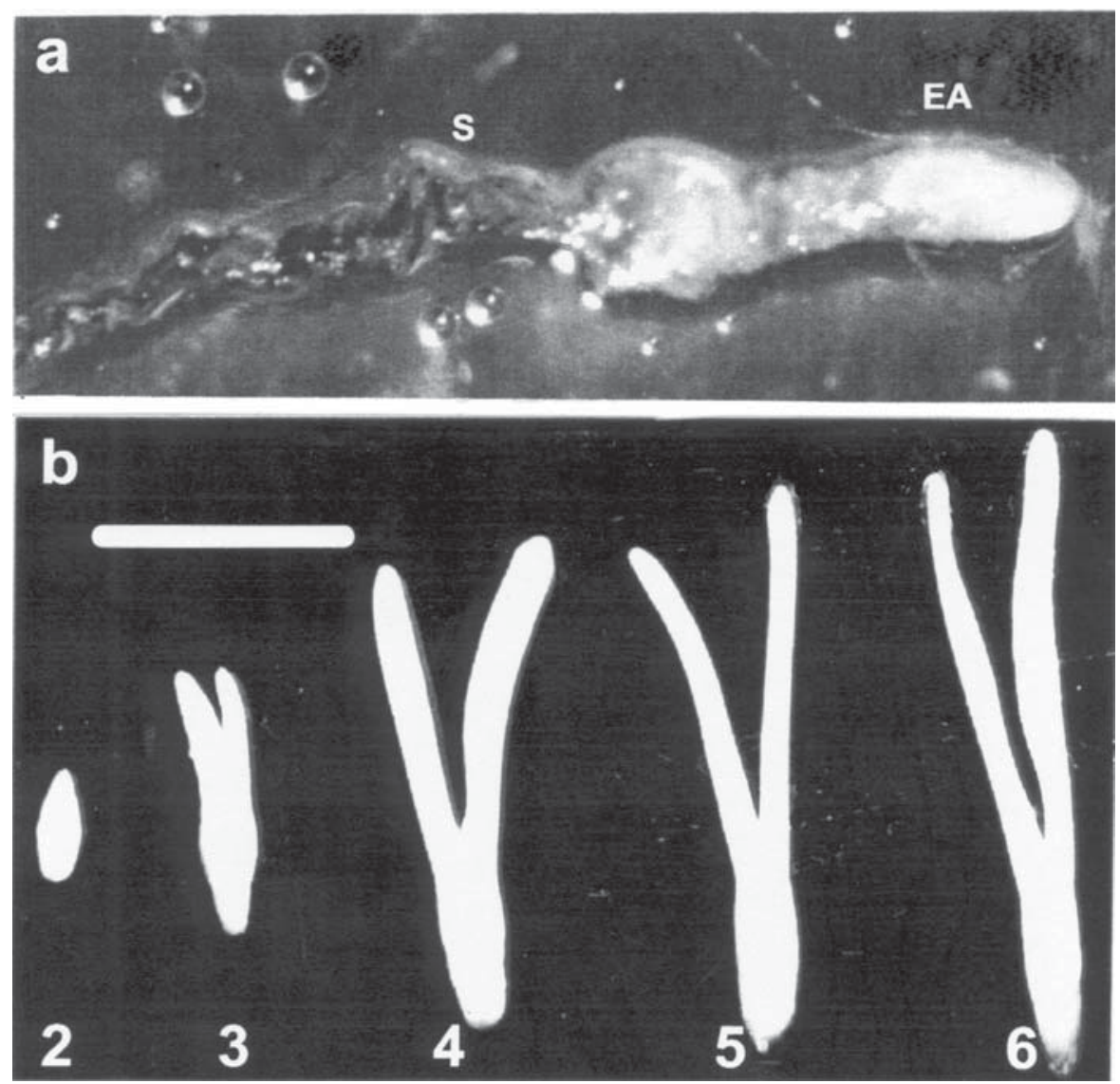

Figure 1. Stages of the embryonic axis development of Araucaria angustifolia seeds collected in different dates (1998). Stage $1\left(\mathrm{Dec}, 10^{\text {th }}\right), 2\left(\mathrm{Jan}, 10^{\text {th }}\right), 3\left(\mathrm{Jan}, 26^{\text {th }}\right), 4\left(\mathrm{Feb}, 11^{\text {th }}\right), 5\left(\mathrm{Mar}, 4^{\text {th }}\right)$ and $6\left(\mathrm{Mar}, 25^{\text {th }}\right)$. a) stage $1(\mathrm{~S}-$ suspensor, EA - embryonic apex); b) stages 2-6. Bar represents $0.5 \mathrm{~cm}$ in (a), and $1 \mathrm{~cm}$ in (b). 
(1990). The mixture was vortexed and incubated at $70^{\circ} \mathrm{C}$ for $50 \mathrm{~min}$; L-proline (100 mg. $\left.\mathrm{ml}^{-1} \mathrm{H}_{2} \mathrm{O}\right)$ was added to each vial, and after $30 \mathrm{~min}$ in the dark, the derivatized PAs were extracted with toluene $(1: 4 \mathrm{v} / \mathrm{v})$. Each sample was analyzed by HPLC in a C18 reverse phase column (Shimadzu Shimpack CLC ODS). The solvents acetonitrile and 10\% acetonitrile in water, $\mathrm{pH} 3.5$, were programmed for the following gradient: $40 \%-70 \%(0.01-5 \mathrm{~min}), 70 \%-100 \%$ $(5-15 \mathrm{~min})$ and $100 \%(15-25 \mathrm{~min})$, at the flow rate of $1 \mathrm{ml} . \mathrm{min}^{-1}$. Excitation and emission wavelengths at 340 and $510 \mathrm{~nm}$, respectively, were used for a fluorescent detector. Peak areas and retention times were measured by comparison with standard PAs: putrescine (Put), spermidine (Spd) and spermine (Spm). Two different aliquots were used for each sample (10 seeds), and three determinations were made for each aliquot. The reported data are averages of convergent determinations.

Dry matter and water content - Fresh matter was determined in the gametophyte, embryonic axis and cotyledon tissues when present. The different materials were maintained for $72 \mathrm{~h}$ at $60^{\circ} \mathrm{C}$, to obtain the dry matter.

\section{Results and Discussion}

Free PAs content in mature seeds of Araucaria angustifolia varied according to the tissue and stage of development. The highest levels were observed in the embryonic axis, at the early stages of development (stage 2), when Put and Spd were the most abundant
PAs (figure 2). The levels of Spm in the initial development of Araucaria angustifolia cotyledons (stage 3), were four times higher than the contents of Put and Spd (figure 2). In mature seeds, when dry matter reaches the maximum (figure 3), the Spm level was higher, followed by those of Put and Spd (figure 2). The same pattern, with higher levels of Spm than of Put, occurred in zygotic embryos of Pinus radiata D. Don (Minocha et al. 1999). However, in mature seeds of Picea abies L. Karst, Put was the most important PA (Santanen \& Simola 1999). According to Galston and Kaur-Sawhney (1990), Put alone could maintain cell proliferation but, the presence of Spd and Spm is essential to induce differentiation in yeast and Daucus carota L. cell cultures. Although evidence has accumulated suggesting an important role for PAs in regulating DNA synthesis and an orderly progression through the cell cycle, a general causal relationship between PAs and cell growth in plants has not yet been unequivocally demonstrated (Kakkar et al. 2000).

The competence of Araucaria angustifolia cultures to produce somatic embryos occurs from very early developmental stages, stage 1 of zygotic embryos (Astarita \& Guerra 1998). This restricted phase of competence could be related with the highest Put content observed in different tissues at the same period (figure 2). The requirement for PAs in the initiation of

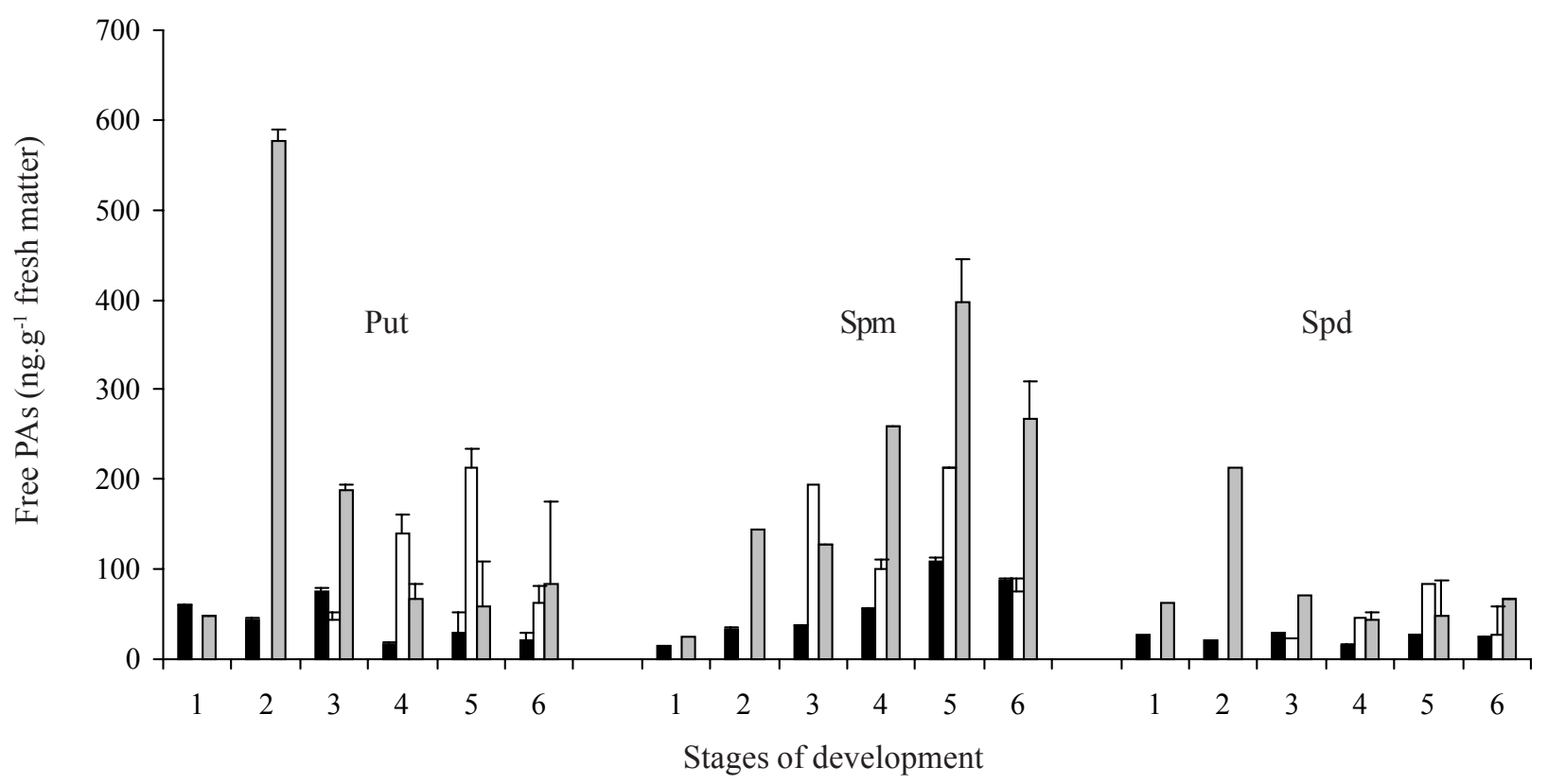

Figure 2. Free PAs content (ng. $\mathrm{g}^{-1}$ fresh matter) in different tissues and stages of seed development in Araucaria angustifolia. Put - putrescine; Spm - spermine; Spd - spermidine. Data are averages of convergent determination of two different aliquots, and three determinations for each aliquot. Stages of development: $\mathbf{\square}=$ Megagametophyte; $\square=$ Cotyledons; $\square=$ Embryonic axis. The vertical bars represent standard error. 


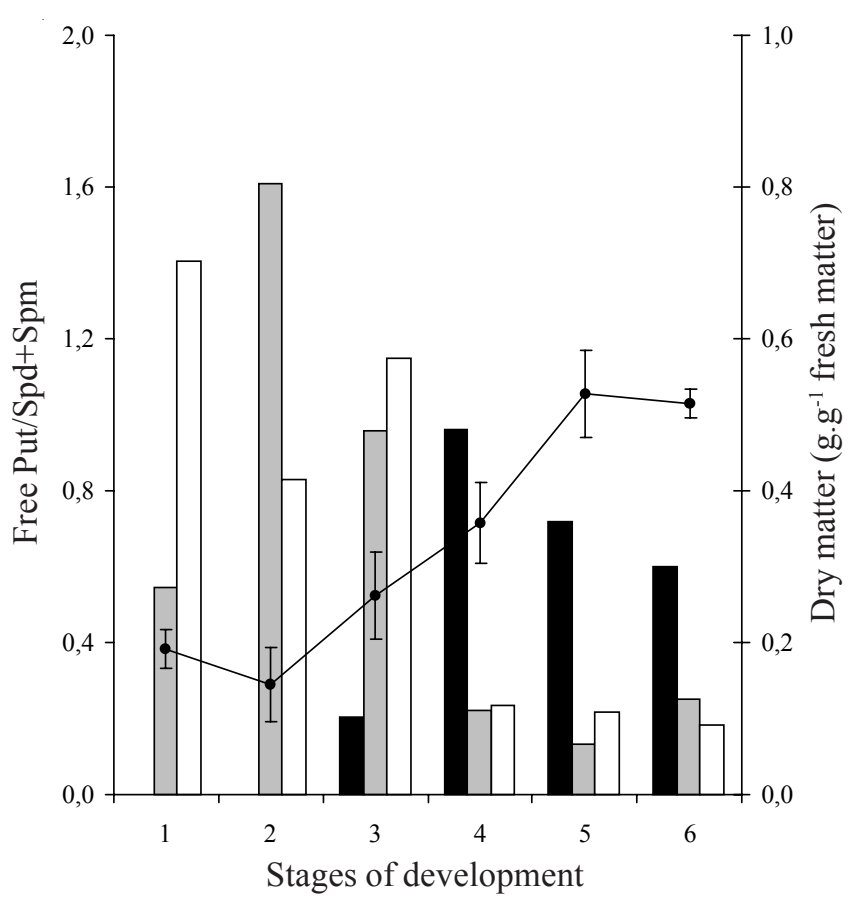

Figure 3. Dry matter and free Put/Spd + Spm ratio in different tissues and stages of seed development in Araucaria angustifolia. Put - putrescine; Spm - spermine; Spd spermidine. The vertical bars represent standard error. Stages of development: $\mathbf{\square}=$ Cotyledons; $\square=$ Embryonic axis; $\square=$ Megagametophyte; $-\bullet-=$ Dry matter.

somatic embryogenesis may not be universal, nor needed during all stages of embryo development (Kakkar et al. 2000). Higher levels of Put than of Spd were reported in embryogenic cell cultures of carrot (Feirer et al. 1984, Robie \& Minocha 1989), but different stages of embryogenesis were not studied. Carrot cells having an excess of Put were shown to be more competent to undergo embryogenesis, but although such cells reached the globular embryo stage, they failed to develop further (Bradley et al. 1984, Bastola \& Minocha 1995). The activities of different PAs could be different and varied at every developmental stage in embryogenic and nonembryogenic cultures (Kakkar et al. 2000). In Picea abies (L.) Karst, Picea glauca Voss and Picea rubens Sarg. (Minocha et al. 1993, Amarasinghe \& Carlson 1994, Amarasinghe et al. 1996), the level of PAs is variable and does not correspond to a standard morphogenetic response. In different angiosperm species, high levels of Put can be effective to inhibit cell proliferation and differentiation (Martin-Tanguy 1997). Andersen et al. (1998) proposed that the stimulation of morphogenetic processes by high levels of Put in cell cultures, reflects a raising in the "turnover" of PAs metabolism, with a consequential reduction in ethylene production. Studies in Picea glauca with inhibitors of PAs biosynthesis indicate that such substances interfere only in the early phases of somatic embryogenesis, without effect on advanced somatic embryos (Kong et al. 1998).

Minocha et al. (1999) observed an increase in PAs content of the embryogenic axis in Pinus radiata D. Don seeds coincident with a decline in the megagametophyte and proposed two possibilities for this response: 1. that there are fluxes of PAs from the megagametophyte to developing embryos and, 2. that there is an increasing PAs biosynthesis in the embryos coincident with a decline in the synthesis and/or an increase in the catabolism of polyamines in the gametophyte.

In the megagametophyte and cotyledons of Araucaria angustifolia seeds, a low level of Spd and a high level of Spm was observed (figure 2). The decrease of Put and the increase of Spm, in the embryonic axis, from stage 3 until the mature seed, suggest two hypothesis: i) an increasing Put conversion to Spd and $\mathrm{Spm}$, resulting in an accumulation of Spm in the tissues or, ii) an increase in diamine-oxidase activity with a consequential increase in Put degradation, with the formation of succinate (Bouchereau et al. 1999).

The relative amount of PAs is correlated with the competence of tissues for somatic embryogenesis (Lee et al. 1997, Kong et al. 1998), to control different physiological events such as tissue rejuvenation (Rey et al. 1998) and the cellular elongation in plants (Shen \& Galston 1985). The Put/Spd+Spm ratio has been correlated with the synthesis of macromolecules (Lin et al. 1984). In Araucaria angustifolia the proportion between the Put levels and the other PAs was higher during the initial phases of seed development, corresponding to the cellular multiplication and elongation (stages 1 to 3 ), with a reduction in the final stages, corresponding to stabilization of the dry matter content (figure 3).

Spm is considered more active than Spd and Put in biological processes (Van den Broeck et al. 1994). PAs are important in the maintenance of the viability of quiescent seeds, by acting on the stabilization of cellular membranes through reducing trans-membrane phospholipid movements, interacting with the nuclear proteins that determine the spaced configuration of DNA, and stimulating the synthesis of pectins and hemicellulose beyond the anti-oxidant effect (Bouchereau et al. 1999).

As morphogenetic events that occur in zygotic and somatic embryogenesis are similar (Dodeman et al. 
1997, Dong \& Dunstan 1999), the knowledge of endogenous changes in PAs could allow for a more strict manipulation of tissue culture conditions, and the obtention of somatic embryogenesis.

Acknowledgements - The authors thank Fapesp and CNPq (Brazil) for grants.

\section{References}

ALTMAN, A. \& LEVIN, N. 1993. Interaction of polyamines and nitrogen nutrition in plants. Physiologia Plantarum 89:653-658.

AMARASINGHE, V. \& CARLSON, J.E. 1994. Subcellular localization of polyamines in embryogenic callus of White spruce (Picea glauca). Canadian Journal of Botany 72:788-793.

AMARASINGHE, V., DHAMI, R. \& CARLSON, J.E. 1996. Polyamine biosynthesis during somatic embryogenesis in interior spruce (Picea glauca $\mathrm{x}$ Picea engelmannii complex). Plant Cell Reports 15:495-499.

ANDERSEN, S.I., BASTOLA, D.R. \& MINOCHA, S.C. 1998. Metabolism of polyamines in trangenic cells of carrot expressing a mouse ornithine decarboxylase cDNA. Plant Physiology 116:299-307.

ARIBAUD, M., KEVERS, C., MARTIN-TANGUY, J. \& GASPAR, T. 1999. Low activity of amine-oxidases and accumulation of conjugated polyamines in disfavour of organic programs in Chrysanthemum leaf disc explants. Plant Cell Tissue Organ Culture 55:85-94.

ASTARITA, L.V. \& GUERRA, M.P. 1998. Early somatic embryogenesis in Araucaria angustifolia. Induction and maintenance of embryonal-suspensor masses cultures. Revista Brasileira de Fisiologia Vegetal 10:113118.

ASTARITA, L.V. \& GUERRA, M.P. 2000. Conditioning of the culture medium by suspension cells and formation of somatic proembryos in Araucaria angustifolia (Coniferae). In Vitro Cellular and Developmental Biology 36:194-200.

ASTARITA, L.V., FLOH, E.I.S \& HANDRO, W. 2003. Free amino acid, protein and water content changes associated with seed development in Araucaria angustifolia. Biologia Plantarum (in press).

BAJAJ, S. \& RAJAM, M.V. 1996. Polyamine accumulation and near loss of morphogenesis in long-term callus cultures of rice. Plant Physiology 112:1343-1348.

BAKER, S.R., JONES, L.H. \& YON, R.J. 1983. Ornithine carbamyltransferase activity and embryogenesis in a carrot cell suspension culture. Phytochemistry 22:2167-2169.

BASTOLA, D.R. \& MINOCHA, S.C. 1995. Increased putrescine biosynthesis through transfer of mouse ornithine decarboxylase cDNA in carrot promotes somatic embryogenesis. Plant Physiology 109:63-71.
BOUCHEREAU, A., AZIZ, A., LARHER, F. \& MARTINTANGUY, J. 1999. Polyamines and environmental challenges: recent development. Plant Science 140:103-125.

BRADLEY, P.M., EL-FIKI, F. \& GILES, K.L. 1984. Polyamines and arginine affect somatic embryogenesis of Daucus carota. Plant Science Letters 34:397-401.

DODEMAN, V.L., DUCREUX, G. \& KREIS, M. 1997. Zygotic embryogenesis versus somatic embryogenesis. Journal Experimental Botany 48:1493-1509.

DONG, J.Z. \& DUNSTAN, D.I. 1999. Cloning and characterization of six embryogenesis-associated cDNA from somatic embryos of Picea glauca and their comparative expression during zygotic embryogenesis. Plant Molecular Biology 39:859-864.

FEIRER, R.P., MIGNON, G. \& LITVAY, J.D. 1984. Arginine decarboxylase and polyamines required for embryogenesis in the wild carrot. Science 223:1433-1435.

FLORES, H.E. \& FILNER, P. 1985. Polyamine catabolism in higher plants: characterization of pyrroline dehydrogenase. Plant Growth Regulation 3:277-291.

GALSTON, A.W. \& KAUR-SAWHNEY, R. 1990. Polyamines. Plant Physiology 94:406-410.

GUERRA, M.P., SILVEIRA, S., SANTOS, A.L.W., ASTARITA, L.V. \& NODARI, R.O. 2000. Somatic embryogenesis in Araucaria angustifolia (Bert.) O. Ktze. In Somatic embryogenesis in woody plants (S.M. Jain, P.K. Gupta \& R.J. Newton, eds.). Kluwer Academic Publishers, Dordrecht, p.457-458.

HEBY, O. \& PERSSON, L. 1990. Molecular genetics of polyamine synthesis in eukaryotic cells. Trends Biochemical Science 15:153-158.

KAKKAR, R.K., NAGAR, P.K., AHUJA, P.S. \& RAI, V.K. 2000. Polyamines and plant morphogenesis. Biologia Plantarum 43:1-11.

KONG, L., ATTREE, S.M. \& FOWKE, L.C. 1998. Effects of polyethylene glycol and methylglyoxal bis (guanylhydrazone) on endogenous polyamine levels and somatic embryo maturation in white spruce (Picea glauca). Plant Science 133:211-220.

LEE, T.M., LUR, H.S. \& CHU, C. 1997. Role of abscisic acid in chilling tolerance of rice (Oryza sativa L.) seedlings. II. Modulation of free polyamine levels. Plant Science 126:1-10.

LIN, P.P.C., EGLI, C.B., LI, G.M. \& MECKEL, L. 1984. Polyamine titer in the embryonic axis and cotyledons of Glycine max L. during seed growth and maturation. Plant Physiology 76:366-371.

MARTIN-TANGUY, J. 1997. Conjugated polyamines and reproductive development: biochemical, molecular and physiological approaches. Physiologia Plantarum 100:675-688.

MINOCHA, S.C., MINOCHA, R. \& ROBIE, C.A. 1990. High performance liquid chromatographic method for the determination of dansyl-polyamines. Journal Chromatography 511:177-183. 
MINOCHA, R., KVAALEN, H., MINOCHA, S.C. \& LONG, S. 1993. Polyamines in embryogenic cultures of Norway spruce (Picea abies) and red spruce (Picea rubens). Tree Physiology 13:365-377.

MINOCHA, R., SMITH, D.R., REEVES, C., STEELE, K.D. \& MINOCHA, S.C. 1999. Polyamines levels during the development of zygotic and somatic embryos of Pinus radiata. Physiologia Plantarum 105:155-164.

MONTAGUE, M.J., KOPPENBRINK, J.W. \& JAWORASKI, E.G. 1978. Polyamine metabolism in embryogenic cells of Daucus carota. I. Changes in arginine decarboxylase activity. Plant Physiology 62:430-433.

MONTAGUE, M.J., ARMSTRONG, T.A. \& JAWORSKI, E.G. 1979. Polyamine metabolism in embryogenic cells of Daucus carota L. II. Changes in intracellular content and rates of synthesis. Plant Physiology 63:341-345.

OWENS, J.N., CATALANO, G. \& AITKEN-CHRISTIE, J. 1997. The reproductive biology of kauri (Agathis australis). IV. Late embryogeny, histochemistry, cone and seed morphology. International Journal of Plant Science 158:395-407.
REY, M., DÍAZ-SALA, C. \& RODRÍGUEZ, R. 1998. Free polyamine content in leaves and buds of hazelnut (Corylus avellana L. cv. Negret) trees subjected to repeated severe pruning. Scientia Horticulturae 76:115-121.

ROBIE, C.A. \& MINOCHA, S.C. 1989. Polyamines and somatic embryogenesis. I. The effects of difluoromethylornithine and difluoromethylarginine. Plant Science 65:445-454.

SANTANEN, A. \& SIMOLA, L.K. 1999. MetaboLism of $\mathrm{L}\left[\mathrm{U}-{ }^{14} \mathrm{C}\right]$-arginine and $\mathrm{L}\left[\mathrm{U}-{ }^{14} \mathrm{C}\right]$-ornithine in maturing and vernalised embryos and megagametophytes of Picea abies. Physiologia Plantarum 107:433-440.

SHEN, H. \& GALSTON, A.W. 1985. Correlations between polyamine ratios and growth patterns in seedling roots. Plant Growth Regulation 3:353-363.

VAN DEN BROECK, D., VAN DEN STRAETEN, D., VAN MONTAGU, M. \& CAPLAN, A. 1994. A group of chromosomal proteins is specifically released by spermine and loses DNA-binding activity upon phosphorylation. Plant Physiolology 106:559-566. 